Sirli Agustiani ${ }^{1}$, Arlina Dewi ${ }^{2}$

${ }^{1}$ Magister Keperawatan, Universitas

Muhammadiyah Yogyakarta

2Magister Administrasi Rumah Sakit,

Universitas Muhammadiyah Yogyakarta

Corresponding Author: Sirli Agustiani

Email: sirliagustiani0@gmail.com

\section{Fulfillment Of Safety And Comfort Needs In Patients with Urinary Catheter: Literature Review}

$\begin{array}{ll}\text { Article Info } & \\ \text { Online } & : \text { http://journal.umy.ac.id/index.php/ijnp } \\ \text { ISSN } & : 25484249 \text { (Print) } \\ & : 2548592 X \text { (Online) } \\ \text { DOI } & : 10.18196 / \text { ijnp.v4i2.10243 }\end{array}$

Background: Discomfort often occurs when catheter placement and also the removal of catheter. In health sector, nursing practice focus on patient quality and safety. Feeling safe is a form of feeling that if not controlled of anxiety. Using urinary catheter will affect to quality of life of patients such as physical, psychological, socio cultural, environmental and spiritual aspects.

Objective: The aims of this study was to describe how the fulfillment of safety and comfort needs in urinary catheter patients.

Method: This study used literature review. The database were PubMed, Google Scholar and ProQuest. The search was restricted to English language articles and limited to last 5 years (2014-2019). Articles should be related to research. This study use main keywords experience AND "urinary catheter*". Only fourteen journals met the eligbility criteria and were review by two researchers.

Result: The Results of article that urinary catheter impact on several aspect of patients such as social aspect patient have limited social interaction, and difficult to adaptation. In psychological aspect, patient feel embarrassed, dissatisfaction, frustation, anxiety, and low self esteem. In physical aspect, patient feel blocking their movement, increase the risk of infection, painful, discomfort, and iritation. In other aspect, the patient has economic problem.

Conclusion: The findings of articles show positive and negative impact for patient's life when urinary catheter inserted. The review provides insight that can be useful for nurses in concerning patient's need about safety and comfort especially patients with urinary catheters.

Keywords: comfort, experience, safety, urinary catheter.

\section{INTRODUCTION}

Elimination is a human basic need that can be interrupted and cause discomfort in life and activities (Siregar, 2004). One of nursing actions that can be done by nurses for fullfilment of elimination need is by catheter placement (Prastia, 2015). Catheter is a tube, hollow, flexible tube that is inserted into the urinary tract and bladder to drain urine (Sunshine Coast Hospital and Health Service, 2017). Around $15-25 \%$ patients treated in the hospital recieve urinary catheter intervention while in the hospital (Centers for Disease Control and Prevention [CDC], 2015). In NHSN 2011 surveillance report, about 45-79\% patients treated in critical care unit used indwelling catheters, $17 \%$ in general wards, $23 \%$ in surgical wards and $9 \%$ in rehabilitation units (Nicolle, 2014).

Urinary catheter placement indication is urinary retention, for urine culture, inserting contrast material as radiological examination, monitoring urine production or fluid balance, 


\section{NUNRSINNG \\ PRACTICES}

measuring urine residue. Urinary catheter placement has contraindications such as urethral stricture, urethral rupture, and urinary tract infection, etc (Nuari \& Widayati, 2017). Patients are felt discomfort from urinary catheter. About $75 \%$ patients with catheter are discomfort, and a half report pain. Patients many activities feel more discomfort, especially in men (Wilde, 2002). Discomfort often occurs when urinary catheter placement and also removal of catheter (Canterbury Continence Forum, 2013).

Using urinary catheter will affect to quality of life of patients such as biological or physical, psychological, socio cultural, environmental and spiritual (Fumincelli et al., 2017). In general, the effect of catheter use on life has an impact on the physical domain of patients such as patients complaining of pain, sick and discomfort (Bai et al., 2015; Wilde, 2002). The psychological aspect for users to make adaptation of psychologically, impact on selfesteem (someone's intimate relationship). Social aspects, patients feel that something is blocking and does not enjoy do social activities, embarrassment when meet other people (McClurg et al., 2018).

Patient also need safety according to basic human need of Abraham Maslow consists of pyhsiological need, love, self esteem, self actualization and safety (Kemenkes RI, 2016). Feeling safe is a form of feeling that if not controlled, it can raises of anxiety. Various effort need to be implement to meet the patient's need for safety and comfort. Therefore, nurses must concerning patient's need and patient priorities (Prinjha \& Chapple, 2013).

Researchers focus on nursing articles because researchers to know and summarize patient's need about comfort and safety for urinary catheter's patient that are reviewed from nursing research. Based on this background, researchers have not found any literature review articles that discuss specifically about fulfillment of safety and comfort needs in urinary catheter patients.

Only one review article (systematic review design and a qualitative metasynthesis review) that discusess the experience of urinary catheter patients inserted, especially psychososial aspects and has not discusses the patient's need for safety and comfort. So, researchers have the desire to conduct literature review about it.

\section{METHOD}

A. Search Method

A search was carried out for articles containing the keywords " (/( experience or impression or expression or fulfillment or need or satisfaction or perception)) OR (convenience or comfort or ease)) OR (secure or safe or calm or peace)) AND (urinary catheter or urinary catheterization or urine cath or self catheterization)". using PubMed, Google Scholar and ProQuest. The search was restricted to English language articles. Articles should be original research and limited to last 5 years (2014-2019). Articles should be related to research about fulfillment of safety and comfort needs in urinary catheter patients.

B. Extraction and Data Review Method

1) Article Selection

Two researchers performed an inital literature screen independently. Articles did not meet the search eligbility criteria were excluded. Articles that meet the inclusion criteria reviewed to see the quality of the research articles.

2) Evaluation of Articles

The findings were discussed until the researchers final selection articles.

\section{RESULTS}

\section{A. Search Results}

From total database, only fourteen articles enrolled inclusion criteria. This figure 1 is article search process from identification, screening, eligbility, and include. 


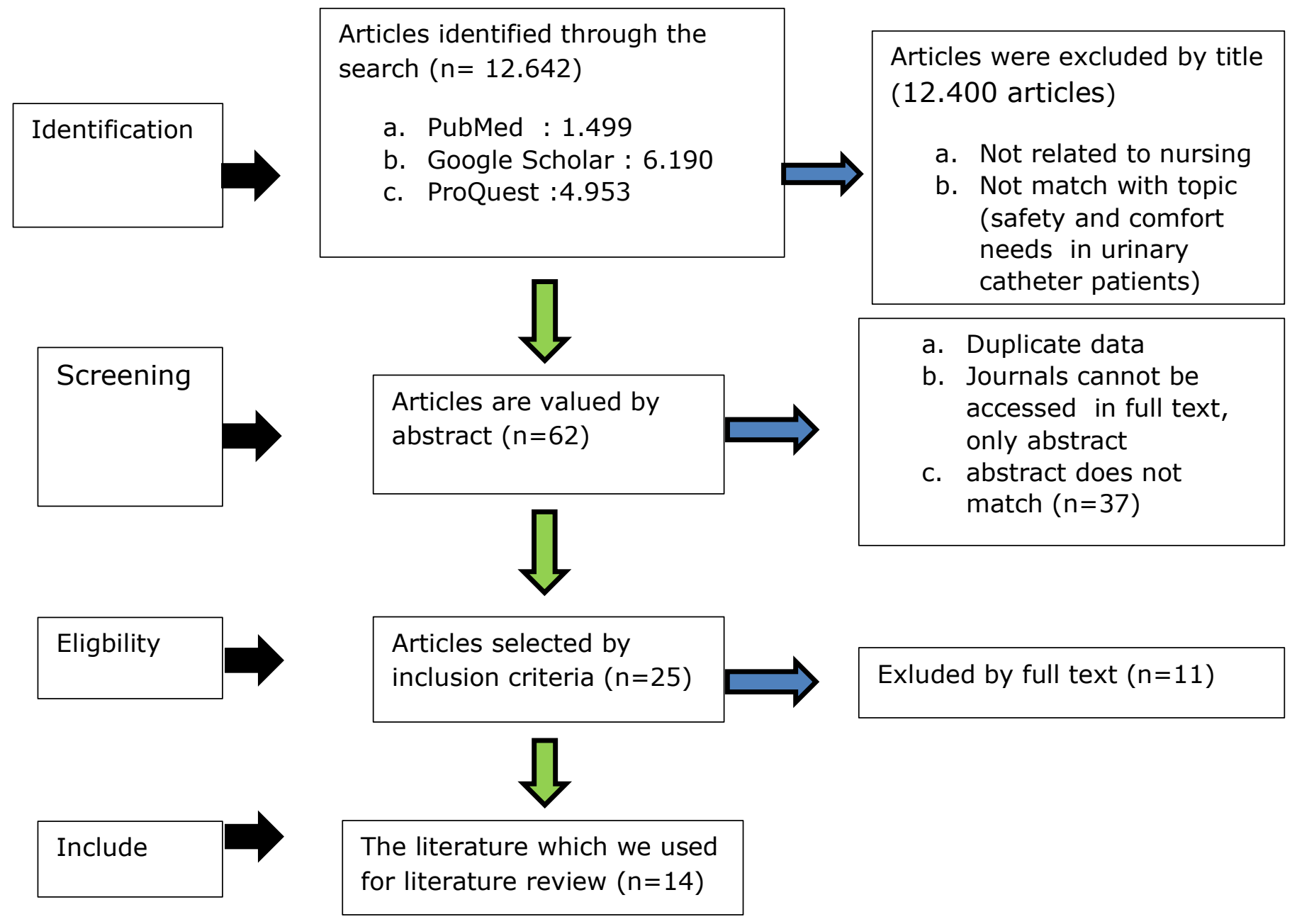

Figure 1. Article Search Process.

\section{B. Patient's Experience}

This literature review focuses on patient's need about safety and comfort especially patients with urinary catheters. The studies were heterogeneous. There were 8 quantitative studies and 6 qualitative studies. The themes were generally similar between those using indwelling and intermitten catheter.

There are several categories found in the finding articles such as in physical aspect, psychological aspect, social aspect and other aspect. In physical aspect, patient feel blocking their movement, increase the risk of infection, painful, discomfort, and iritation. In psychological aspect, patient feel embarrassed, dissatisfaction, frustation, anxiety, and low self esteem. In social aspect, patient have limited social interaction, and difficult to adaptation. In other aspect, the patient has economic problem.

Two articles discuss how the patient's experiences based on the type of urinary catheter and patient's reason using catheter. The result show the patient's reason using urinary catheter are urinary retention, post stroke or trauma, incontinence, and post urology surgery (Darbyshire et al., 2016; Laan et al., 2019).

The details of these studies are presented in table 1. Patients say using urinary catheter feel embarrassed, discomfort, painful, unfree, blocking their movement (Darbyshire et al., 2016; Laan et al., 2019; Trautner et al., 2019). This in supported by research from Safdar et al., (2016). 


\section{NUNRSINNG \\ PRACTICES}

Patients also feel with urinary catheter will increase the risk of infection. With insertion of foley catheter, patient feel dissatisfaction, barriers to social interaction, frustation and pain (Gidaszewski et al., 2018; Kandadai et al., 2016). Other hand, some patients feel comfortable with urinary catheter because they have difficulty urinating (CobussenBoekhorst et al., 2016; Trautner et al., 2019). Some patients have intermittent catheterization this that it is scary and painful. But it did not turn out as thought (CobussenBoekhorst et al., 2016).

According to Logan (2017) that when inserting, $81 \%$ feel pain, $59 \%$ describe more comfortable, while $70 \%$ said it was comfortable when catheter was removed. According to Logan (2015), 93\% had no pain during catheter placement, $93 \%$ had no pain when removing, $86 \%$ rarely or never experience discomfort. Compared with male patients, women report greater comfort when use urinary catheter ( $\mathrm{Hu}$ et al., 2019). On the other hand, respondent assume that they do not need to go to bathroom to urinate (Safdar et al., 2016).

Patients prefer suprapubic catheter than urethral catheter (Chapple et al., 2015). That is supported by Fowler et al (2014), female patients feel urethral catheter cause discomfort when sitting so they turn to suprapubic catheter. Single use catheter (SUC) is more convenient than multiple use catheter (MUC). But patients who have stoma in abdomen are more comfortable using MUC than SUC (Park et al., 2017). Patients have experienced infections when this catheter is inserted, such as fever, pain, fatigue, spasms in the leg area so they have to go back and forth to the hospital.

Initially, some patients said they were afraid the first time they would undergo the catheterization process. The catheter insertion process scared her because there were several catheter products that were stiff so that when the catheter was inserted it caused blood to flow in the urethra. With a community, patients feel more open, share information with each other so that patients can share knowledge as long as they do the catheterization themselves and how the catheter is processed. Patients can travel to places they want to go (Goldstine et al., 2019).

All patients said their level of activity was disturbed (Atakro et al., 2017). The patient said it was uncomfortable and painful with this catheter inserted. The patient says that his sexual life is limited. Patients feel that their sexual activities are impeded by the presence of a catheter. The patient also tries to hide the catheter from his partner. With the catheter in place, patients reduce their social activities for fear of creating odors that can cause embarrassment. Patient preferred to stay at home.

In the work environment patients say the catheter has a negative effect for them. Many patients experience economic hardship due to the insertion of this catheter so they have to depend on their family and partner. So that patients feel that this catater makes the role of patients seeking money obstructed. Even though the patient is elderly, the patient says that he wants to work.

\section{DISCUSSION}

\section{A. Types of Catheter}

Single use catheter (SUC) is more convenient than multiple use catheter (MUC). But patients who have stoma in abdomen are more comfortable using MUC than SUC (Park et al., 2017). Patients reported that SPC (suprapubic catheter) more comfortable than urehtral catheter. Usually, Urethral is first choice in necessary. Suprapubic catheter low of risk of infection, more hygienic, comfort, increase of self image, good sexual relation (Chapple et al., 2015). Kandadai et al (2016) explain that catheter with valve (VC) and foley catheter (FC) users report that it has similar catheter related pain.

\section{B. Physical Aspect}

Patients have experienced infections when the catheter inserted. Patients with urinary 
catheter feel discomfort, painful, unfree, blocking their movement. The patient also said that it was difficult to determine the position of the catheter or urine bag because of the fear of falling. The patient thinks that the urinary catheter is addictive and this makes the patient obstructed in physical activity (Jaquet et al., 2009). For men, pain during sexual activity is because something sticks to the penis area. For female, catheter moves during activity, so it causes friction in genitalia and make sore (Wilde, 2002).

In contrast, Respondent assume that they do not need to go to bathroom to urinate. the patient does not experience pain, especially the patient feels safe at night (Ramm \& Kane, 2011). Patients feel free because their urinary problems are resolved. Urinary catheter is advantageous for patients in need of elimination (physiological) (Nyman et al., 2013).

\section{Psychological Aspect}

Patients fear for first time and when the catheter was inserted it caused blood to flow in the urethra, so it increases the patient's fear. Patient also feel dissatisfaction, frustation, and anxiety. Anxiety happened when the urinary catheter leaks so that the patient does not feel free (Kelly et al., 2014). The patient says that his sexual life is limited. Patients say their sexual activity is impaired, so it make the patient's self-esteem decreased.

Some patients say sex is very important and the catheter really affects it. When inserting a catheter, the opposite sex makes the patient uncomfortable because it shows the intimate part (Nyman et al., 2013). Catheter affects selfesteem, loss of confidence in sexual activity. The disease can causes disability, loss of bladder muscle strength, disturbances in urination and sexual activity (Chapple et al., 2014).

Patient also tries to hide the catheter from his partner. So that when the partner finds out the situation the patient often quarrels with his partner. With the catheter in place, patients reduce their social activities because fear of creating odors that can cause embarrassment (Chapple et al., 2015).

In contrast to the study of Godfrey (2008), catheters as part of life without harming their identity, remain confident, feel more relieved, and describe urinary catheters as their friends and become more satisfied, Patients initially considered having a catheter inserted is bad but after some time the catheter was a gift.

\section{Social Aspect}

Patient have barriers to social interaction. (Kralik et al., 2007) said urinary catheters make patients embarrassed by their social environment. So the patient tries to hide the presence of the catheter. The patient also tries not to tell his friends and neighbors about the existing catheter. The patient said that as long as the catheter was in place, the patient became social isolation. This is supported by Shaw et al. (2008), some patients find it difficult to socialize and become obstacles to socializing.

In Contrast to the study of (Goldstine et al., 2019), patient says there needs to be a community for people who have urinary catheters in life. With a community, patients feel more open, can share information with each other so that patients can share knowledge as long as they do the catheterization themselves and how the catheter is processed.

\section{E. Other Aspect}

In the work environment patients say the catheter has a negative effect for them. Patients experience economic hardship due to the insertion of this catheter so they have to depend on their family and partner. So that patients feel that this catater makes the role of patients seeking money obstructed.Some patients want to get a lot of information from their doctor regarding the catheter (Logan et al., 2008). In contrast to study of (Shaw et al., 2008b), in the work environment, some patients do not experience difficulties with this catheter, instead catheters help the patient. 


\section{NUNRSINGG \\ PRACTICES}

Table 1. Data Analysis Matrix for Articles Used in Literature Review.

\begin{tabular}{|c|c|c|c|c|}
\hline Autors & $\begin{array}{l}\text { Types } \\
\text { Catheter }\end{array}$ & Design & Sample & Result \\
\hline Darbyshire et al (2016) & $\begin{array}{l}\text { Urinary } \\
\text { catheter } \\
\text { (general) }\end{array}$ & Survey research & $\begin{array}{l}50 \text { patients from } 17 \\
\text { different ward }\end{array}$ & $\begin{array}{l}\text { Patients feel leaking }(32 \%) \text {, } \\
\text { embarrassement (24\%), discomfort } \\
(26 \%) \text {, pain }(26 \%) \text {, blocking their } \\
\text { movement }(24 \%), 8 \% \text { finding their } \\
\text { catheters restrictive. } 14 \% \text { felt have coped } \\
\text { without catheter. Reason for using } \\
\text { catheter include urinary retention, post } \\
\text { injury or post stroke, urological surgery } \\
\text { and incontinencia urine. }\end{array}$ \\
\hline Hu et al (2019) & $\begin{array}{l}\text { Urinary } \\
\text { catheter } \\
\text { (general) }\end{array}$ & $\begin{array}{l}\text { Survey research } \\
\text { or } \quad \text { study } \\
\text { investigated }\end{array}$ & 321 patients & $\begin{array}{l}\text { Women report easier and more } \\
\text { comfortable use of urinary catheter. }\end{array}$ \\
\hline Laan et al (2019) & $\begin{array}{l}\text { Urinary } \\
\text { catheter } \\
\text { (general) }\end{array}$ & RICAT-study & $\begin{array}{l}49 \text { patients had } \\
\text { urinary catheter }\end{array}$ & $\begin{array}{l}\text { Symptoms from insertion, patients } \\
\text { reported no symptom ( } 75 \%) \text {, pain } \\
(14,6 \%) \text {, restriction in daily activities } \\
(31,3 \%) \text {. Statements from urinary } \\
\text { patients feel satisfied }(63,8 \%) \text {, no } \\
\text { symptom }(50 \%) \text {, rather have no urinary } \\
\text { catheter }(65,2 \%) \text {. It's no difference in } \\
\text { outcomes of statements and symptoms } \\
\text { between age and gender. More than half } \\
\text { of the patients would rather have a } \\
\text { urinary catheter for urinary } \\
\text { incontinence. }\end{array}$ \\
\hline Trautner et al (2019) & $\begin{array}{l}\text { Indwelling } \\
\text { urinary catheter }\end{array}$ & $\begin{array}{l}\text { Descriptive } \\
\text { analysis (part of } \\
\text { prospective } \\
\text { observational } \\
\text { study) }\end{array}$ & 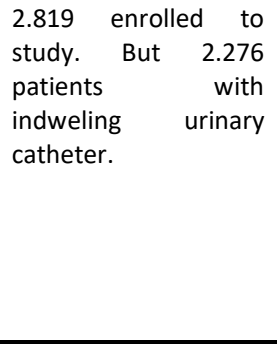 & $\begin{array}{l}\text { Positive comments by patients with } \\
\text { catheter, patient can sleep at night and } \\
\text { sit was a relief to have the catheter. More } \\
\text { than } 80 \% \text { negative comments about } \\
\text { urinary catheter (pain, irritation, } \\
\text { discomfort, interference with activities of } \\
\text { daily living) because many patients } \\
\text { mentioned the trouble were made by } \\
\text { health care provider when insertion and } \\
\text { removal. }\end{array}$ \\
\hline Chapple et al (2015) & $\begin{array}{l}\text { Long term } \\
\text { catheter }\end{array}$ & $\begin{array}{l}\text { Narrative } \\
\text { interviews }\end{array}$ & $\begin{array}{l}36 \text { users (men and } \\
\text { women) }\end{array}$ & $\begin{array}{l}\text { Some respondents said that SPC } \\
\text { (suprapubic catheter) more comfort, } \\
\text { hygiene, better for sexual than urethral } \\
\text { catheter.It also cause of pressure sores. } \\
\text { Patient reported symptoms show that a } \\
\text { SPC is more comfortable and better } \\
\text { tolerated than a urethral catheter. }\end{array}$ \\
\hline $\begin{array}{l}\text { Cobussen-Boekhorst } \\
\text { et al (2016) }\end{array}$ & $\begin{array}{l}\text { Indwelling } \\
\text { catheter }\end{array}$ & $\begin{array}{l}\text { Qualitative } \\
\text { multicentre }\end{array}$ & $\begin{array}{l}124 \text { inclusion criteria } \\
\text { patients of a } \\
\text { quantitative } \quad \text { study } \\
\text { with } \\
\text { diagnoses. }\end{array}$ & $\begin{array}{l}\text { Patients need take a rest, less } \\
\text { incontinence material. Pain has } \\
\text { disappeared. Before catheterization, } \\
\text { patients thought it would be painful but } \\
\text { it just expected. }\end{array}$ \\
\hline Fowler et al (2014) & $\begin{array}{l}\text { Indwelling } \\
\text { catheter }\end{array}$ & $\begin{array}{l}\text { Qualitative } \\
\text { research }\end{array}$ & $\begin{array}{l}27 \text { community } \\
\text { indwelling long term } \\
\text { catheter. } 14 \text { females } \\
\text { (4 urethral, } 10 \\
\text { suprapubic) and } 13 \\
\text { males (6 urethral, } 7 \\
\text { suprapubic). }\end{array}$ & $\begin{array}{l}\text { Respondents linked indwelling catheter } \\
\text { to physical discomfort. Women } \\
\text { particularly found the urethral catheter } \\
\text { uncomfortable beacuse they felt they sat } \\
\text { on it for much of the day. This was cited } \\
\text { as one of the reasons to change } \\
\text { suprapubic catheter. Participants also } \\
\text { reported pain when the catheter } \\
\text { blocked. }\end{array}$ \\
\hline Logan (2015) & $\begin{array}{l}\text { Intermitten } \\
\text { catheter }\end{array}$ & Survey research & 99 male & $\begin{array}{l}\text { When removing the urinary catheter, } \\
93 \% \text { patients no pain. when removing the } \\
\text { catheter } 93 \% \text { experience no pain. After } \\
\text { catheterization, } 86 \% \text { rarely experienced } \\
\text { discomfort. }\end{array}$ \\
\hline Logan (2017) & $\begin{array}{l}\text { Intermitten } \\
\text { catheter }\end{array}$ & Survey research & $\begin{array}{l}49 \text { participants were } \\
\text { recruited. } 9 \text { were not } \\
\text { new to ISC. }\end{array}$ & $\begin{array}{l}\text { 81\% participants did not feel pain when } \\
\text { inserting catheter, describe comfortable } \\
\begin{array}{ll}(59 \%) \text { and discomfort } & (27 \%) . \quad 70 \%\end{array}\end{array}$ \\
\hline
\end{tabular}


participants were no discomfort after catheter removed. Comparing the result , felame patients had discomfort than men when insertion of catheter and remove it.

\begin{tabular}{|c|c|c|c|c|}
\hline Safdar et al (2016) & $\begin{array}{l}\text { Indwelling } \\
\text { catheter }\end{array}$ & Qualitative study & $\begin{array}{l}20 \text { patients with } \\
\text { indwelling urinary } \\
\text { catheter (9 men, } 11 \\
\text { women) }\end{array}$ & $\begin{array}{l}30 \% \text { patients reported indwelling } \\
\text { catheter increase of infection. } 25 \% \\
\text { patients get limitation to mobility, } \\
\text { patients also feel pain and discomfort. } \\
\text { But other hand, } 45 \% \text { patients reported } \\
\text { that catheter more comfortable because } \\
\text { they did not to go to bathroom in the } \\
\text { night and not to get up. }\end{array}$ \\
\hline (Goldstine et al., 2019) & $\begin{array}{l}\text { Intermitten } \\
\text { catheter }\end{array}$ & Qualitative study & $\begin{array}{l}25 \text { adult patient, } \geq 18 \\
\text { years old }\end{array}$ & $\begin{array}{l}\text { Patients have experienced infections } \\
\text { when this catheter is inserted, such as } \\
\text { fever, pain, fatigue, spasms in the leg } \\
\text { area so they have to go back and forth to } \\
\text { the hospital. Patients say catheters are } \\
\text { very helpful to them and more practical. } \\
\text { Initially, some patients said they were } \\
\text { afraid the first time they would undergo } \\
\text { the catheterization process. The catheter } \\
\text { insertion process scared her because } \\
\text { there were several catheter products } \\
\text { that were stiff so that when the catheter } \\
\text { was inserted it caused blood to flow in } \\
\text { the urethra. } \\
\text { With a community, patients feel more } \\
\text { open, share information with each other } \\
\text { so that patients can share knowledge as } \\
\text { long as they do the catheterization } \\
\text { themselves and how the catheter is } \\
\text { processed. Patients can travel to places } \\
\text { they want to go. }\end{array}$ \\
\hline (Atakro et al., 2017) & $\begin{array}{l}\text { Indwelling } \\
\text { catheter }\end{array}$ & Qualitative & $\begin{array}{l}19 \text { patients (men) } \\
\text { were interviewed }\end{array}$ & $\begin{array}{l}\text { All patients said their level of activity was } \\
\text { disturbed. The patient said it was } \\
\text { uncomfortable and painful with this } \\
\text { catheter inserted. } \\
\text { The patient says that his sexual life is } \\
\text { limited. The patient also tries to hide the } \\
\text { catheter. } \\
\text { With the catheter in place, patients } \\
\text { reduce their social activities for fear of } \\
\text { creating odors that can cause } \\
\text { embarrassment. In the work } \\
\text { environment patients say the catheter } \\
\text { has a negative effect for them. } \\
\text { Many patients experience economic } \\
\text { hardship due to the insertion of this } \\
\text { catheter so they have to depend on their } \\
\text { family and partner. So that patients feel } \\
\text { that this catater makes the role of } \\
\text { patients seeking money obstructed. Even } \\
\text { though the patient is elderly, the patient } \\
\text { says that he wants to work. }\end{array}$ \\
\hline Park et al (2017) & $\begin{array}{l}\text { Intermitten } \\
\text { catheter }\end{array}$ & Survey research & $\begin{array}{l}45 \text { pediatric patients } \\
\text { who underwent } \mathrm{CIC} \\
\text { for neurogenic } \\
\text { bladder. }\end{array}$ & $\begin{array}{l}\text { Result that patients in all group, gave } \\
\text { higher scores in favor of SUC (ease of use, } \\
\text { convenience, discreetness, symptomatic } \\
\text { benefit), even though they may or may } \\
\text { not significant. Single use catheter (SUC) } \\
\text { is more convenient than multiple use } \\
\text { catheter (MUC). But patients who have } \\
\text { stoma in abdomen are more comfortable } \\
\text { using MUC than SUC. }\end{array}$ \\
\hline Kandadai et al (2016) & $\begin{array}{l}\text { Foley catheter } \\
\text { and } \quad \text { Valve } \\
\text { catheter }\end{array}$ & $\mathrm{RCT}$ & $\begin{array}{l}49 \text { subjects. } 24 \text { use } \\
\text { foley catheter and } 25 \\
\text { valve catheter. }\end{array}$ & $\begin{array}{l}\text { Catheter with valve (VC) and foley } \\
\text { catheter (FC) users report that it has } \\
\text { similar catheter related pain. Feeling of } \\
\text { frustation and limited social activities } \\
\text { have significant results. }\end{array}$ \\
\hline
\end{tabular}




\section{NURRSING \\ PRACTICES}

\section{CONCLUSSION}

Conclussion of this literature review show that patients feel shy when using urinary catheter, discomfort, painful, unfree, and there are obstacle to their movement. It also can cause irritation, increase the risk of infection, cause dissatisfaction, disruption of social interaction, frustation when using the urinary catheter. But there are several articles found that patient feel comfort because they don't need to go to bathroom to urinate and catheter is useful for patients. The Role of nurses in providing nursing care is needed, especially handling negative experiences of patients urinary catheter inserted. So that, patient feel safe and comfort using catheter. The nurse should provide holistic care for urinary catheter patient inserted.

\section{ETHICAL APPROVAL}

This research does not require ethical approval.

\section{REFERENCES}

Atakro, C. A., Boni, G. S., \& Gross, J. (2017). Socioeconomic impact of indwelling urethral Catheter: The experiences of patients discharged from the Volta Regional Hospital of Ghana. 1(2), 9.

Canterbury Continence Forum. (2013). CATHETER CARE GUIDELINES 2013.

Centers for Disease Control and Prevention [CDC]. (2015). Catheter-associated Urinary Tract Infections (CAUTI). U.S. Department of Health \& Human Services.

Chapple, A., Prinjha, S., \& Feneley, R. (2015). Comparing Transurethral and Suprapubic Catheterization for Long-term Bladder Drainage: A Qualitative Study of the Patients' Perspective. Journal of Wound, Ostomy and Continence Nursing, 42(2), 170-175.

https://doi.org/10.1097/WON.00000000 00000096.

Chapple, A., Prinjha, S., \& Salisbury, H. (2014). How users of indwelling urinary catheters talk about sex and sexuality: A qualitative study. British Journal of General Practice, 64(623), e364-e371. https://doi.org/10.3399/bjgp14X680149

Cobussen-Boekhorst, H., Hermeling, E., Heesakkers, J., \& van Gaal, B. (2016). Patients' experience with intermittent catheterisation in everyday life. Journal of Clinical Nursing, 25(9-10), 1253-1261. https://doi.org/10.1111/jocn.13146.

Darbyshire, D., Rowbotham, D., Grayson, S., Taylor, J., \& Shackley, D. (2016). Surveying patients about their experience with a urinary catheter: Urinary catheter experience. International Journal of Urological Nursing, 10(1), 14-20. https://doi.org/10.1111/ijun.12085.

Fowler, S., Godfrey, H., Fader, M., Timoney, A. G., \& Long, A. (2014). Living With a Longterm, Indwelling Urinary Catheter: Catheter Users' Experience. Journal of Wound, Ostomy and Continence Nursing, 41(6), 597-603. https://doi.org/10.1097/WON.00000000 00000069.

Fumincelli, L., Mazzo, A., Martins, J. C. A., Henriques, F. M. D., \& Orlandin, L. (2017). Quality of life of patients using intermittent urinary catheterization. Revista Latino-Americana de Enfermagem, 25(0). https://doi.org/10.1590/15188345.1816.2906.

Gidaszewski, B., Khajehei, M., \& McGee, T. (2018). Outpatient cervical ripening: Discomfort/pain during speculum and Foley catheter insertion. Midwifery, 67, 57-63.

https://doi.org/10.1016/j.midw.2018.09. 012.

Godfrey, H. (2008). Living with a long-term urinary catheter: Older people's experiences. Journal of Advanced Nursing, 62(2), 180190. https://doi.org/10.1111/j.13652648.2007.04584.x.

Goldstine, J., Leece, R., Samas, S., \& Zonderland, R. (2019). In Their Own Words: Adults' Lived Experiences With Intermittent Catheterization. Journal of Wound, Ostomy and Continence Nursing, 46(6), 513-518. https://doi.org/10.1097/WON.00000000 00000591.

Hu, F.-W., Chang, C.-M., Su, P.-F., Chen, H.-Y., \& Chen, C.-H. (2019). Gender differences in inappropriate use of urinary catheters among hospitalized older patients. Journal 
of Women \& Aging, 31(2), 165-175. https://doi.org/10.1080/08952841.2018. 1423918.

Jaquet, A., Eiskjaer, J., Steffensen, K., \& Laursen, B. S. (2009). Coping with clean intermittent catherization - experiences from a patient perspective: Patients' experiences with poor bladder emptying. Scandinavian Journal of Caring Sciences, 23(4), 660666. https://doi.org/10.1111/j.14716712.2008.00657.x.

Kandadai, P., Duenas-Garcia, O. F., Pilzeck, A. L., Saini, J., Flynn, M. K., Leung, K., \& Patterson, D. (2016). A Randomized Controlled Trial of Patient-Controlled Valve Catheter and Indwelling Foley Catheter for Short-term Bladder Drainage: Female Pelvic Medicine \& Reconstructive Surgery, 22(2), 88-92. https://doi.org/10.1097/SPV.0000000000 000249.

Kelly, L., Spencer, S., \& Barrett, G. (2014). Using intermittent self-catheters: Experiences of people with neurological damage to their spinal cord. Disability and Rehabilitation, 36(3),

220-226. https://doi.org/10.3109/09638288.2013. 785606.

Kemenkes RI. (2016). Kebutuhan Dasar Manusia I. Pusdik SDM Kesehatan.

Kralik, D., Seymour, L., Eastwood, S., \& Koch, T. (2007). Managing the self: Living with an indwelling urinary catheter. Journal of Clinical Nursing, 16(7b), 177-185. https://doi.org/10.1111/j.1365-

2702.2005.01440.x.

Laan, B. J., Nieuwkerk, P. T., \& Geerlings, S. E. (2019). Patients knowledge and experience with urinary and peripheral intravenous catheters. World Journal of Urology. https://doi.org/10.1007/s00345018-02623-4.

Logan, K. (2015). The male experience of ISC with a silicone catheter. British Journal of Nursing, 24(Sup9), S30-S34. https://doi.org/10.12968/bjon.2015.24.S up9.S30

Logan, K. (2017). The female experience of ISC with a silicone catheter. British Journal of Nursing, 26(2), 82-88. https://doi.org/10.12968/bjon.2017.26.2. 82

Logan, K., Shaw, C., Webber, I., Samuel, S., \& Broome, L. (2008). Patients' experiences of learning clean intermittent selfcatheterization: A qualitative study. Journal of Advanced Nursing, 62(1), 3240. https://doi.org/10.1111/j.13652648.2007.04536.x.

Nicolle, L. E. (2014). Catheter associated urinary tract infections. 8.

Nuari \& Widayati. (2017). Gangguan pada sistem perkemihan \& penatalaksanaan keperawatan. CV Budi Utama.

Nyman, M. H., Gustafsson, M., Langius-Eklöf, A., \& Isaksson, A.-K. (2013). Patients' experiences of bladder emptying in connection with hip surgery: An issue but of varying impact. Journal of Advanced Nursing, 69(12), 2686-2695. https://doi.org/10.1111/jan.12156.

Park, C. H., Jang, G., Seon, D. Y., Sun, I. Y., Ahn, C. H., Ryu, H., Lee, S. H., \& Kim, K. M. (2017). Effects on Quality of Life in Patients with Neurogenic Bladder treated with Clean Intermittent Catheterization: Change from Multiple Use Catheter to Single Use Catheter. Childhood Kidney Diseases, 21(2), 142-146. https://doi.org/10.3339/jkspn.2017.21.2. 142.

Prastia, R. D. (2015). Perbandingan Respon Nyeri Pada Prosedur Kateterisasi Urin Pria Dengan Teknik Pengolesan Jelly Pada Kateter Dan Penyemprotan Jelly Langsung Ke Dalam Urethra Di Instalasi Gawat Darurat RSUD Dr. Soedarso. 12.

Ramm, D., \& Kane, R. (2011). A qualitative study exploring the emotional responses of female patients learning to perform clean intermittent self-catheterisation: CISC: the emotional response of female adults. Journal of Clinical Nursing, 20(21-22), 3152-3162.

https://doi.org/10.1111/j.13652702.2011.03779.x.

Safdar, N., Codispoti, N., Purvis, S., \& Knobloch, M. J. (2016). Patient perspectives on indwelling urinary catheter use in the hospital. American Journal of Infection Control, 44(3), e23-e24. 


\section{NUNRSING \\ PRACTICES}

https://doi.org/10.1016/j.ajic.2015.10.01 1.

Shaw, C., Logan, K., Webber, I., Broome, L., \& Samuel, S. (2008a). Effect of clean intermittent self-catheterization on quality of life: A qualitative study. Journal of Advanced Nursing, 61(6), 641-650. https://doi.org/10.1111/j.13652648.2007.04556.x.

Trautner, B. W., Saint, S., Fowler, K. E., Van, J., Rosen, T., Colozzi, J., Chopra, V., Lescinskas, E., \& Krein, S. L. (2019). What do patients say about their experience with urinary catheters and peripherally inserted central catheters? American Journal of Infection Control, 47(9), 11301134.
Shaw, C., Logan, K., Webber, I., Broome, L., \& Samuel, S. (2008b). Effect of clean intermittent self-catheterization on quality of life: A qualitative study. Journal of Advanced Nursing, 61(6), 641-650. https://doi.org/10.1111/j.13652648.2007.04556.x.

Sunshine Coast Hospital and Health Service. (2017). Home management of your catheter. Queensland Government. https://doi.org/10.1016/j.ajic.2019.05.03 1

Wilde, M. H. (2002). Understanding Urinary Catheter Problems: From the Patient's Point of View. Home Healthcare Nurse: The Journal for the Home Care and Hospice Professional, 20(7), 449-455. https://doi.org/10.1097/00004045200207000-00010. 